化すべき酸化劑を含有すべからず且故に試樂は常に新製のものを用ふべし.（畑） 水酸化物の研究 Britton u. Wilson: Soc., 2550-2557（1932） 著者は $\mathrm{HgCl}_{2}$, $\mathrm{HgBr}_{2}, \mathrm{Hg}(\mathrm{CN})_{2}, \mathrm{HgSO}_{4}, \mathrm{Hg}\left(\mathrm{NO}_{3}\right)_{2}, \mathrm{Hg}\left(\mathrm{ClO}_{4}\right)_{2}, \mathrm{Hg}\left(\mathrm{C}_{2} \mathrm{H}_{3} \mathrm{O}_{2}\right)_{2}$ t $\mathrm{NaOH}$ で電

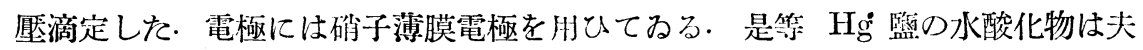
そ特定の $\mathrm{pH}$ 値で生成する. 著者は $\left[\mathrm{Hg}^{\circ}\right]\left[\mathrm{OH}^{\prime}\right]^{2}$ の溶解積を $1 \cdot 10^{-29}\left(18^{\circ}\right)$ と 假定して水酸化物の沈搌する $\mathrm{pH}$ 値から各 $\mathrm{Hg}$ 留の解離恒數, 加水分解恒數等 を算出した. 本誌, 601 號, 51 頁參照. C. 1933. I. 2034

電壓滴定に合金電極の應用Ａ. Banchetti：Gazz. chim. ital., 62, 999-1010, 1011-28（1932） 著者は $\mathrm{pH}=4-10$ の緩衝液に白金極を浸し,之と合金電極 との電位差站に $\mathrm{N}$ 甘承電極との電位差を测定した。次の命金は電壓アシジヌト リーの電極として不適當である. ヂュラルミン, $\mathrm{Fe}-\mathrm{Cr}, \mathrm{Fe}-\mathrm{Ni}-\mathrm{Mo}, \mathrm{Fe}-\mathrm{W}, \mathrm{Fe}-$ $\mathrm{Ni}-\mathrm{W}, \mathrm{Fe}-\mathrm{V}$. 又金䐂及 $\mathrm{Sn}$ 女不適算である. $\mathrm{Fe}_{2} \mathrm{O}, 3 \mathrm{~Pb}, \mathrm{Pyrit}, \mathrm{Fe}-\mathrm{Mo}, \mathrm{Fe}-\mathrm{Ti}$, $\mathrm{Co}-\mathrm{Cr}, \mathrm{Cu}-\mathrm{Ti}$ 等必適當とは云へぬ. 侦用に耐へるのはV $2 \Lambda$-Stahl, $1 \mathrm{~g}, \mathrm{Fe}-\mathrm{Ta}$, $\mathrm{Ni}$, 永和銅, 真鍮である. 著者は醋酸の定量に眞鍮, V $2 \mathrm{~A}$ の電極を用ひて滿足 な結果を得てるる. 將來此種の合金電極がキンヒドロン電極の適用出來婸合に 賞用せられるであらう, C. 1933. I. 2143.

(下澤)

\title{
IV 藥局學
}

錠劑の製法に就て E. Schroff：Pharm. Ztg. 7S, 471-473 u. 480-482 (1933) 銫劑の一般製造及注意を記し就中次のもの等の例に就いて詳細說明を試みた： アスピリン錠；バルビタール錠；フェノバルビタール錠；キノフェン錠；鋇痛錠; 燐酸コデイン錠；アミノピリン錠；ヂギタリス葉鋜・芳香ホルムアルデヒド錠； ヘキサメチレンテトラミン錠; 薄荷腦十アミノ安息香酸エチル鋜, 薄荷腦十ユー カリ油鉟・溶性バルビタール錠；薄荷油錠；フェナセチン錠；サリチル酸アンチ ピリン錠; 複方ポドフイルリン錠; サリチル酸フェニル錠; 人工ェムス泉䯠（食 鹽 1 ：重曹 2) 錠；サントニン十カカオ鉈!; 催眠藥錠；スルホナール錠；ヨート 硫黄錠.

オキシシアン水銀錠に就て C. V. Bordeianu：Arch. Pharm. 271, 149 (1933) オキシシアン水銀錠の分析はそれに用ひた賦形藥に依つて非常に困難なるのみな ら时には不能の場合さへあるが著者は此問題に關し詳細な研究をなし, 佾獨逸 
局方 6 版オキシシアン水銀 $\left(\mathrm{Hg}(\mathrm{CN})_{2} \cdot \mathrm{HgO} 36 \%+\mathrm{Hg}(\mathrm{CN})_{2} 64 \%\right.$ 混合物 $)$ 及 オキシシアン水銀 $\left(\mathrm{Hg}(\mathrm{CN})_{2} \cdot \mathrm{HgO}\right)$ の種くの賦形藥に依る溶解度に對する影響 几就て, 又その溶液の耐久力, 及賦形藥に依り $\mathrm{Hg}(\mathrm{CN})_{2} \cdot \mathrm{HgO}$ が外科器具へ如何 に作用するかを報告し終りに種ふの鍷劑製法にも言及した。

(渡部)

新藥 Orbinal C. A. Rojahn u. J. A. Müller : Apoth. Ztg. 48, 310 (1933) 本品はピロ燐酸ナトリウムより成る白㶵結晶性粉末でアルカリ性の味を有し, 結 晶水を含み水に溶くればアルカリ性を呈し, 液は硝酸銀により白色沈垽を生ず, 迷 朦作用站に後作用なき睡眠妿亚である，用量０.75-0.85g. 製造者： Orbio-Werke, Braunswig.

(渡部)

新藥 Ganiwol-N. C. A. Rojahn u. E. Wirth: Apotrh. Ztg 48, 310 本品 は白色結性粉末の, 食㿼及艺确の味を有し水に容易に溶け, 液はラクムス紙に中性 を呈す, 定性站に定量試驗の結果は無水芒确 $25 \%$, 食監 $60 \%$ 及硝酸ナトリウム $15 \%$ 監臟結石治潦藥, 製造者不前,

(渡部)

新藥 Aci-steril Pharm. Zentrh ت4, 292 (1933) 組成: Methylendiphosphorsaures Natrium $\mathrm{CH}_{2}\left(\mathrm{NaHPO}_{4}\right)_{2}+$ Hexamethylentetramin. 適應症：腎孟炎，

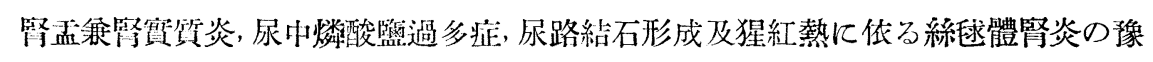
防, 製造者: Heyl \& Co., Chem.-pharm. Fabrik A.-G., Berlin N 65. （渡部）

新薬 Inhepton Pharm. Zentrh. 7-1, 292 本品は肝臟つ抗貧血作用之砒素, ストリキニーネ及燐の興奮强壯性とを利朋して臓器機能療法に基いて製した筋肉 冈注射用强壮藥で, 本品 $1 \mathrm{cc}$ 中には Hepracton (Pharm. Zentrh. 72, 810, (1931 參照) $0.83 \mathrm{cc}$ ，モノメチール亞砒酸ソーダ $0.05 \mathrm{~g}$ ，确酸ストリキニーネ $0.0005 \mathrm{~g}$ 及グリ七口燐酸ソーダ $0.045 \mathrm{~g}$ 老含む, 適應症：出血性, 毒性站に體質性貧血, 製 造者メルク.

(渡部)

\section{V. 贜器 藥品化學}

Follikel-Hormon の構造 A. Butenandt. H. A. Weidlich \& H. 'Thompson : B. 66, 601-604, (1933)

I 及 II は夫љ Follikel-Hormon $\mathrm{C}_{18} \mathrm{H}_{22} \mathrm{O}_{2}$ 及 Follikel-Hormonhydrat $\mathrm{C}_{18} \mathrm{H}_{24} \mathrm{O}_{3}$ の想像式である. II は Marrian 及 Doicy によつて KOH 熔融して Phenoldicarbonsäure $\mathrm{C}_{18} \mathrm{H}_{22} \mathrm{O}_{5}$ (III) になるととが知られた. Butenandt 等は III を 